のり面緑化の一工法・植生筒袋工によるのり面樹林化

\author{
浪越博之 ${ }^{1} \cdot$ 鈴木正人 $^{1} \cdot$ 亀岡敬洋 ${ }^{2}$
}

\title{
Establishment of Woody Plant Communities on the Artificial Slopes by the Revegetation Technique with the Tubate Bags Containing Seeds and Soil
}

\author{
NAMIKoshi, Hiroyuki ${ }^{1}$, SuzUKI, Masato ${ }^{1}$ and KAMEOKA, Takahiro ${ }^{2}$
}

\section{1. はじめに}

大規模な自然開発が進む中，地球環境の保全，破 壊された生態系の回復が各地で強く求められてい る。JH 四国支社・香川管理事務所では, 高速道路と 環境との共存を目的とし, 高松自動車道府中湖パー キングエリア (上り線) の東側園地（約 $5,000 \mathrm{~m}^{2}$ ) を対象に周辺環境と調和のとれたビオトープを創造 することにした。本文はビオトープ創造に関連し て, 建設当時にトンネル掘削時発生した岩塊（花崗 岩）で造成された園地部のり面を早期に樹林化する ため, (1) 草本系のり面を簡単な方法で木本系のり面 にする, (2) 少ない費用で最大の効果を得たい，を目 的に，播種による樹林化試験施工を実施した概要を まとめたものである。

\section{2. 工法選定の対象}

本試験は，野鳥を主体とするビオトープの創造の ため, 周辺のり面をより自然に近く多様性に富む生 態系緑化，樹林化について検討した。樹林化の工法 選定にあたり播種工，植生基材吹付，植生マット， 植生土のう, 植栽工, 植生筒袋工を比較検討したが, 最終的に植生筒袋工を採用した。なお，今回の採用 理由は以下の 3 点である。

\footnotetext{
日本道路公団 四国支社 香川管理事務所

2 四国ロードサービス㧣) 香川作業所
}

1）既に草生地となっている箇所に対して, 種子か らの樹林化が比較的容易である。

2）樹木植栽を行った箇所や周辺地に対して, 徐々 に郷土樹種の群落に移行するよう, 人為的に誘 導することができる。

3）ビオトープの創造は,生態系の多様性を保つた めに小規模工事が多くならざるを得ないため, 施工方法としては重機類を用いず個々の場所に きめ細かく対応できる工法で，しかも簡便であ る。

\section{3. 試験施工概要}

\section{1 試験施工の場所}

高松自動車道・府中湖パーキング（上り線）園地 部および本線のり面

図 1 にその位置を示し, 図 2 にのり面の状況を示 した。

\section{2 試験施工面積}

$3,800 \mathrm{~m}^{2}$ （使用筒袋 531 袋）

3.3 施工期間

平成 10 年 5 月 21 日 5 月 30 日

3.4 施工方法

3.4.1 使用材料（植生筒袋工）

植生筒袋工とは，種子，肥料，壤土，その他栄養 基材を配合し, 網袋に充填して施工地に敷設するも ので，充填物は網袋に包まれているため流亡が少な く，柔軟性があるので地盤に密着し，比較的安定し 


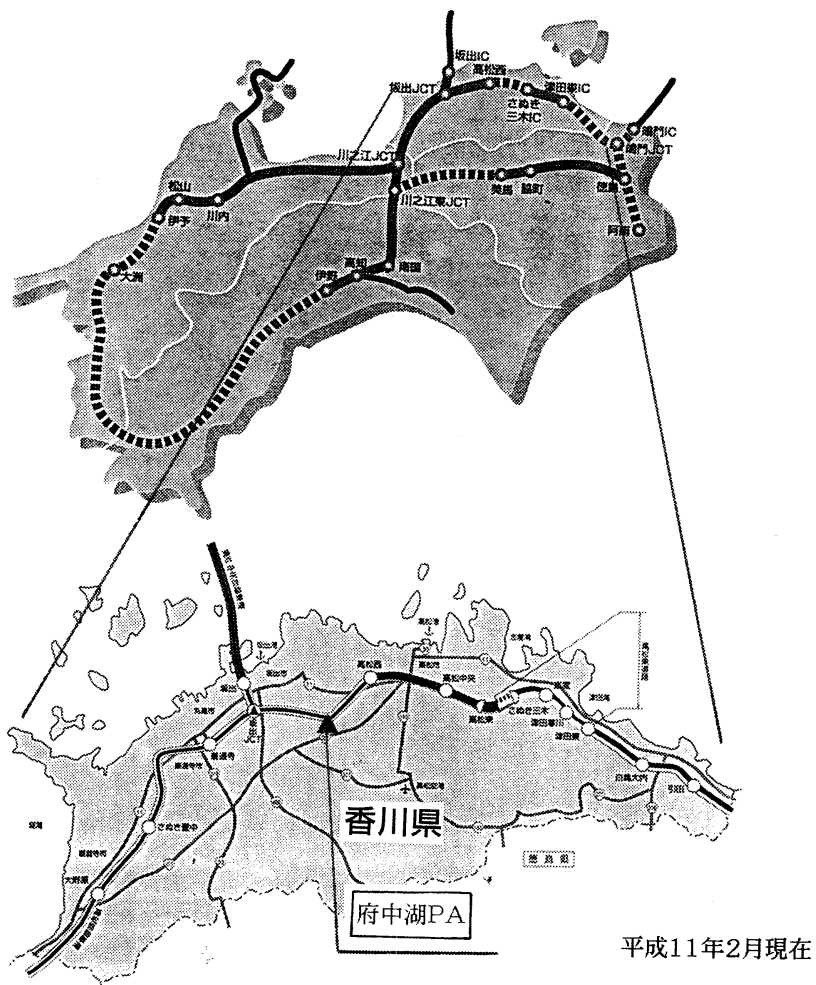

図 1 位置図

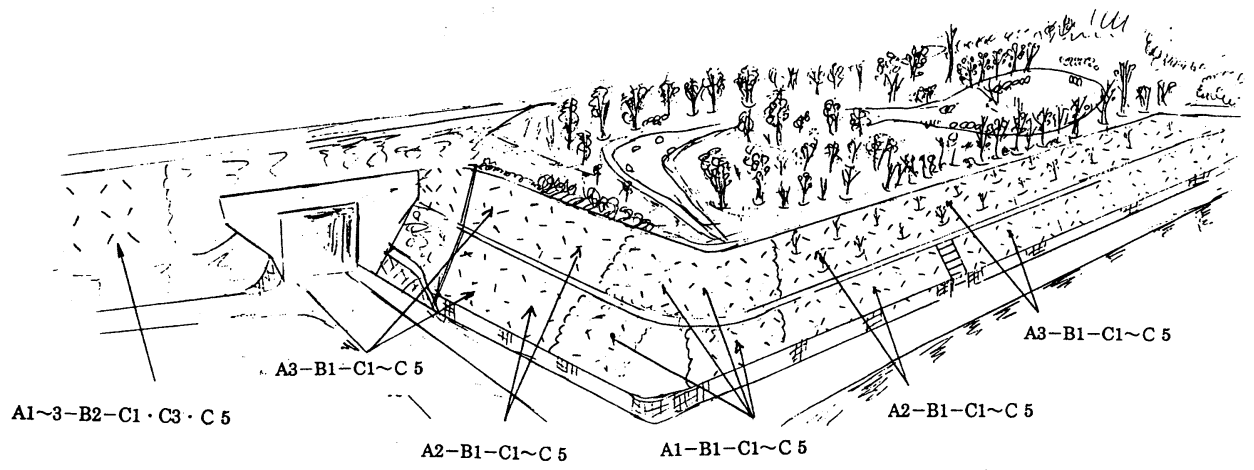

図 2 のり面状況図

た植生基盤が得られる。今回は直径 $8 \mathrm{~cm}$, 長さ $1 \mathrm{~m}$ の筒状のものを試験施工用に製作した（写真 1 , 図 3)。

3.4.2 材料・壤土 ・ 種子等の配合

基材の配合は，植生土のう・マット工等の過去の 実績と経験をもとに植生基材（バーク堆肥）60\%， 土（砂袞土） $15 \%$, 土壤改良材 (バーミキュライト・ クンタン) $15 \%$, 保水材（吸水性ポリマー添加紙）
$10 \%$ とし, 木本類を生育させる目的で土壌活性剂 を，また，肥料は成分配合 $(\mathrm{N}: \mathrm{P}: \mathrm{K}=6: 38: 6)$ のものを使用した。

今回, 製造した植生筒袋 1 本当たりの工場出荷時 の平均重量は, 約 $2,550 \mathrm{~g}$ で, 植生基材および肥料 の配合は表 1 のとおりである。

使用した樹種は試験地で生育しやすい 11 樹種の 内から $3 \sim 5$ 樹種の組合せとした（表 2 ）。選定にあ 
表 1 植生筒袋の内容

\begin{tabular}{|c|c|c|c|c|c|}
\hline \multirow{2}{*}{ 項目 } & \multirow{2}{*}{ 内 容 } & \multirow{2}{*}{ 比率 } & \multicolumn{2}{|c|}{ 1袋当たりの重量 } & \multirow{2}{*}{ 備 考 } \\
\hline & & & 保水材入り & 保水材なし & \\
\hline \multirow[t]{6}{*}{ 配合基材 } & バーク堆肥 & $60 \%$ & 約 $1,520 \mathrm{~g}$ & 約 $1,540 \mathrm{~g}$ & \\
\hline & 砂壌土～植壌土 & $15 \%$ & $610 \mathrm{~g}$ & $610 \mathrm{~g}$ & \\
\hline & 土壌改良材（バーミキュライト） & $10 \%$ & $250 \mathrm{~g}$ & $250 \mathrm{~g}$ & \\
\hline & 保水材 & $10 \%$ & $25 \mathrm{~g}$ & - & 呼水性ポリマー添加紙 \\
\hline & 土袞改良材（クンタン） & $5 \%$ & $105 \mathrm{~g}$ & $110 \mathrm{~g}$ & もみがら炭 \\
\hline & 土壌活性剤（バーディーオール） & & $10 \mathrm{~g}$ & $10 \mathrm{~g}$ & \\
\hline \multirow[t]{2}{*}{ 肥料 } & 化成肥料（グリーンマップII） & & $20 \mathrm{~g}$ & $20 \mathrm{~g}$ & $\begin{array}{l}\mathrm{N}-\mathrm{P}-\mathrm{K} \quad 6-38-6 \\
\text { (超緩効性) }\end{array}$ \\
\hline & 化成肥料 & & $10 \mathrm{~g}$ & $10 \mathrm{~g}$ & $\mathrm{~N}-\mathrm{P}-\mathrm{K} \quad 15-15-15$ \\
\hline
\end{tabular}

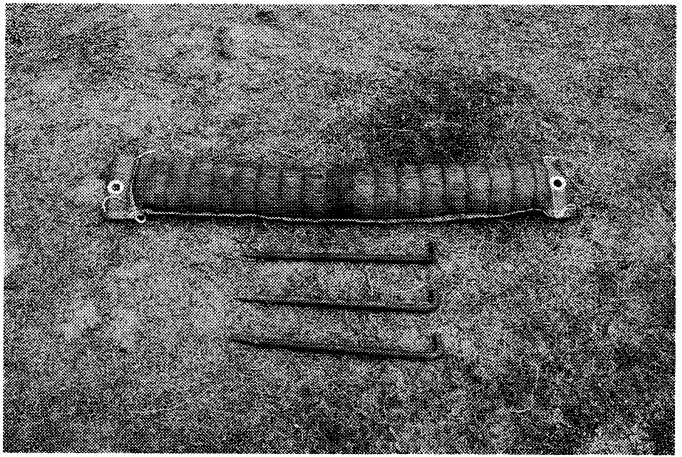

写真 1 筒袋とアンカーピン

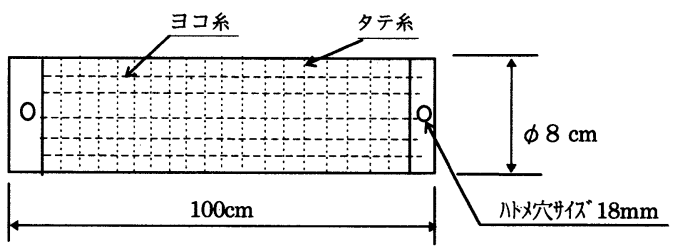

図 3 植生筒袋

たっては, 下記の項目に配慮し, 発芽試験を実施し 決定した。

1）近隣に生育している樹木（郷土樹種）である。

2）導入樹種は複数にしたほうが自然 (雑木林) を 再生できるため混播する。

3）適切な配合を選定するため, 種々の組合せと する。

種子は現地で 1 袋につき $2 \sim 3 \mathrm{~cm}$ の深さに各々 5 粒ずつ差し込んだ。

\section{4 .3 施工・配置・施工条件}

植生筒袋の配置方法には縦列, 斜め列, 菱形, W,
表 2 種子配合

\begin{tabular}{|c|c|}
\hline 区分 & 種 子 \\
\hline $\mathrm{C} 1$ & $\begin{array}{l}\text { アラカシ・クスノキ・スダジイ・ヤマモモ・ } \\
\text { ヤマハゼ }\end{array}$ \\
\hline $\mathrm{C} 2$ & アラカシ・クスノキ・スダジイ \\
\hline $\mathrm{C} 3$ & $\begin{array}{l}\text { シャリンバイ・ウバメガシ・ネズミモチ・ア } \\
\text { キグミ・ヤマハゼ }\end{array}$ \\
\hline $\mathrm{C} 4$ & シャリンバイ・ウバメガシ・ネズミモチ \\
\hline $\mathrm{C} 5$ & $\begin{array}{l}\text { ヤマザクラ・シャリンバイ・アキグミ・オチ } \\
\text { ヤノキ }\end{array}$ \\
\hline
\end{tabular}

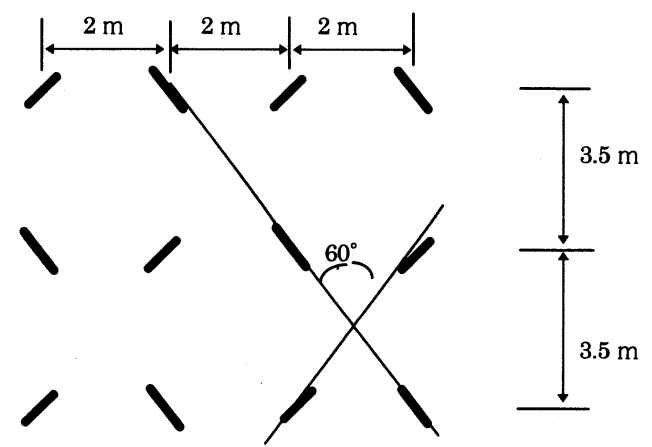

図 4 植生筒袋工配置図 (八の字張り)

$\mathrm{V}, \mathrm{X}$,八の字等の設置方法があるが, 試験施工では 植生筒袋の基本配置は, 今までの知見より, 横 $2 \mathrm{~m}$, 縦 $3.5 \mathrm{~m}$ 間隔の八の字張りで計画し (図 4), $100 \mathrm{~m}^{2}$ に 15 袋を設置することとした（写真 2)。 植生筒袋の敷設条件の評価をするために,

1）のり面の草の上に直に配置する。

2）草刚りをしたのり面に設置する。

3）草刈りしたのり面に溝を切って筒袋を半分埋 
表 3 組合せ施工数

\begin{tabular}{|c|c|c|c|c|c|}
\hline \multirow{2}{*}{ 植生基材 } & \multirow{2}{*}{ 種子配合 } & \multicolumn{3}{|c|}{ 設置方法 } & \multirow{2}{*}{ 備 考 } \\
\hline & & A 1 草上 & A 2 草刚 & A 3 溝切 & \\
\hline \multirow{5}{*}{$\begin{array}{c}\text { 保水材あり } \\
\text { B } 1\end{array}$} & $\mathrm{C} 1$ & 30 袋 & 30 袋 & 30 袋 & \multirow{5}{*}{ 東向き及び北向き } \\
\hline & $\mathrm{C} 2$ & 30 袋 & 30 袋 & 30 袋 & \\
\hline & C 3 & 30 袋 & 30 袋 & 30 袋 & \\
\hline & $\mathrm{C} 4$ & 30 袋 & 30 袋 & 30 袋 & \\
\hline & C 5 & 30 装 & 30 装 & 30 装 & \\
\hline \multirow{3}{*}{$\begin{array}{c}\text { 保水材なし } \\
\text { B } 2\end{array}$} & $\mathrm{C} 1$ & 9 袋 & 9 袋 & 9 袋 & \multirow{3}{*}{ 北向きのみ } \\
\hline & $\mathrm{C} 3$ & 9 袋 & 9 袋 & 9 袋 & \\
\hline & C 5 & 9 袋 & 9 袋 & 9 袋 & \\
\hline
\end{tabular}

(1)植生筒袋の設置方法：A 1 ：のり面の草の上に設置する方法。

A 2：草刚りをしたのり面に設置する方法。

A 3：草刚りしたのり面に, 溝を掘り植生筒袋を半分埋める方法。

(2)植生基材の質：B 1：保水材あり。

B 2：保水材なし。

(3)方向については, 東向きと北向き。

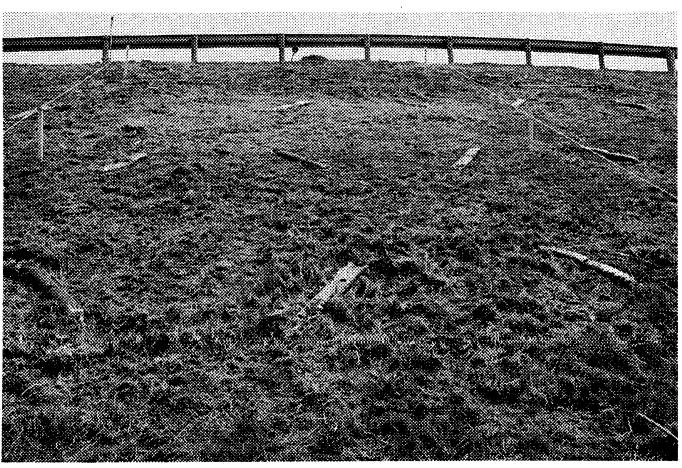

写真 2 植生筒袋施工完了

めて設置する。

の 3 タイプとした。また, 日当たり条件の差が発芽 に影響するかどうかを確かめるため, 北向き斜面と 東向き斜面とに施工した（表 3 ）。

作業は, 次の順序に行った。

1）発芽試験の実施。

2）木本種子の選別を行う。

3）配置展開図より現地に割付けを行う。

4) 草刚りが必要な区間 A 2, A 3 の草を刈り取 る。

5）筒袋の設置付置の芯出しを行う。

6）筒袋を運搬, 配置し，アンカーピンで固定する (困 5)。

7）木本種子を筒装の中に差し入れる。

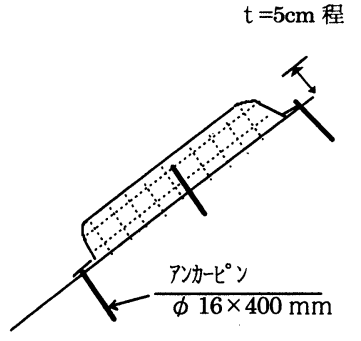

図 5 敷設図

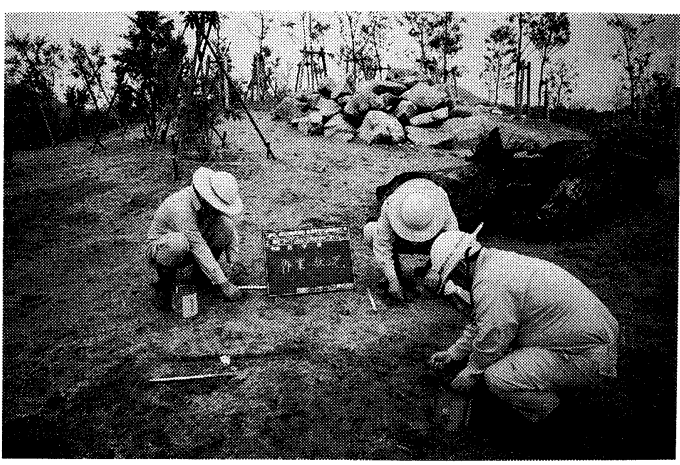

写真 3 直播 (平場)

\section{4. その他の試験施工}

ビオトープ内の平場・築山・築堤を近い将来には 種子からの木本植物に交代させることを想定し, 植 栽木の間に穴を掘って，3～5 粒の種子を直播き（手 


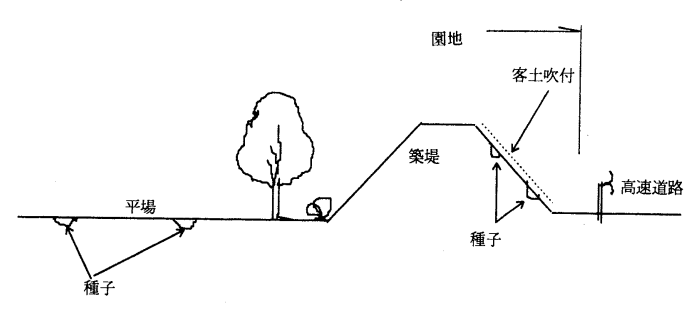

図 6 直播き工法

播き) した (写真 3 )。穴の大きさは径 $5 \mathrm{~cm}$ 程度, 深 さは種子の 2 3 倍以下とした。また, 築堤の高速道 路側のり面には, 直播きした上から客土吹付（厚さ $2 \mathrm{~cm}$ 程度) を行った（図 6)。

\section{5. 今後の課題}

今回の試験施工を踏まえ, 今後の検討事項と課題 についてまとめると，次のようになる。

1）今回は,試験施工ということで現地にて種子を 筒袋に差し込む方法を取ったが，今後の施工では種 子配合を事前に決定し，工場で種子を混入したもの を製品として出荷する。その結果, 種子の使用量が 多くなり, 少し割高になるかもしれない。また, 種 子による差込深さの決定（種子径の 2 倍程度）に課 題が残る。

2) 施工時期の検討。施工時期により木本植物の 種子の入手が困難なものもある。種子の選定と確保 を施工の 1 年前から準備・計画する必要がある。ま た，付近の自然林で採取した種子を含めて，種子の 貯蔵, 管理方法の確立が必要である。

3） $\phi 16 \times 400 \mathrm{~mm}$ のアンカーピンを使用したが,
のり面状況によっては $\phi 13 \times 200 \mathrm{~mm}$ 程度で良い のではないか。

4）新設地山のり面と既設草本のり面とを比較し, 工法の検討をする必要がある。

5）草刚り, 溝切りは人手がかかるので, 草の中に 筒袋を設置しても被圧されずに発芽, 生育しなけれ ばならない。

6）5）に反することであるが, 草のあるのり面での 測量作業（設置場所の位置出し）は煩雑である。し たがって, 今回の成果をみて, より簡易な配置, 芯 出し方法を検討する。

7）発芽しなかった筒袋は，再度，種子を入れて使 用することが可能かどうか今後の試験で確認する必 要がある。

\section{6. 追跡調査}

調票を定め, 施工後 1 年間は月に 1 回程度, 発芽, 生育状況を施工筒袋全数について追跡調査中であ る。その後は年 1 回程度の生育確認をする。

\section{7. おわりに}

のり面樹林化工法として簡便で個々の場所にきめ 細かく対応できる植生筒袋工の試験施工を信州大学 山寺喜成教授のご指導のもと, (株) 新日本緑化のご 協力で無事施工できましたことを心より感謝の意を 表す。また, 園地内の平場, 築堤では木本種子を直 播きした施工方法も実施しており，これらの結果が でるのは少なくとも数年先のこととなる。その成果 については後日報告することとする。

(1999. 3.11 受理) 